\title{
Redefining Masculinity and Femininity on Violent Extremism and Terrorism: The Case of 2018 Surabaya Bombings
}

\author{
G M Drajat ${ }^{1}$, F R Pertiwi ${ }^{2}$ \\ 1,2President University, Cikarang, Indonesia \\ ${ }^{1}$ gibran.mahesa@president.ac.id, ${ }^{2}$ femirachmap@gmail.com
}

\begin{abstract}
This paper aims to evaluate the attributes of masculinity and femininity in violent extremism and terrorist attack using 2018 Surabaya Bombings as a case study. Much of the literature on the subject attaches the combative quality and violence to men while women assume the supporting and non-violent role as mother and wife. This labeling begins to drift as women who are recruited to violent extremist groups, particularly those of radical Islamists, directly engage in perpetrating terrorist act. This is especially evident when women and children participated as combatant in the bombing of three churches in the city of Surabaya, Indonesia in May of 2018. Given the unprecedented shift in the nature of terrorism since ISIS extended its influence to Southeast Asia, there is a need to examine whether the current gender analysis pertaining to violent extremism remains applicable to explain that change. To determine whether the conceptualization of masculinity and femininity needs to be redefined amidst such change, this paper will conduct a literature review on the two concepts. Subsequently, the 2018 Surabaya Bombings are accounted before an assessment is made as to whether redefinition of the two concepts is necessary to strengthen the accuracy of gender analysis on violent extremism and terrorism.
\end{abstract}

Keywords: 2018 Surabaya Bombings, Gender Analysis, Masculinity and Femininity, Terrorism, Violent Extremism.

\section{INTRODUCTION}

When it comes to the subject of violent extremism and terrorist acts, the dichotomy between masculinity and femininity is framed in a way that men are associated with agent of violence while women take on a more traditional and supporting role of its male counterpart. With the rise of pro-Islamic State group particularly in Indonesia, coupled by their recent attack on three churches at the city of Surabaya, there is a need to revisit whether such conceptualization of masculinity and femininity is still applicable with regards to the classification of gender roles in violent extremism. While women are largely perceived as victims in the discourse of violent extremism [1, Para. 4], there is a widening participation of women in advancing the cause of such violent extremist group. This increase in women's participation is most evident as the pro-Islamic State (IS) began to surface and extends its organizational networks in Indonesia. For this reason, the labelling of traditional and supporting role of women needs to be closely re-evaluated with the understanding that social 
construction of masculinity and femininity is driven by norms and expectations that stems from within the violent extremist group itself.

\section{RESEARCH METHOD}

In order to explain the change that occurs in the gender roles between men and women, and thus its corresponding attributes to masculinity and femininity, this paper conducts a literature review on the conceptual dichotomy between the two concepts. Subsequently, the review will be applied to the changing norms and trends of female combatants in violent extremist group using 2018 Surabaya Bombing as a case study. In the end, the paper calls for the need to redefine masculinity and femininity that intertwines with the change in gender roles within violent extremist group.

\section{RESULTS AND DISCUSSION}

The 2018 Surabaya Bombings was a series of terrorist attacks that happened over the span of May 13-14, 2018. It initially took place on May 13, 2018 wherein a family of six, including two children, targeted three churches in the city of Surabaya, Indonesia. According to the BBC [12, Para. 7] and Schulze [11, p. 1], the father, by the name of Dita Oepriapto, drove a car bomb into the grounds of Surabaya Center Pentecostal Church. His wife, Puji Kuswati and their two daughters blew themselves up at Diponegoro Indonesian Christian Church. And their two teenage sons, Yusuf Fadhil and Firman Halim, "rode motorcycles into Santa Maria Catholic Church and detonated explosives they were carrying [12, Para. 9]." The same evening a family of six, comprises of a father, a mother, and their four children, carried out a terrorist attack involving a premature bomb explosion at an apartment in Sidoarjo, a regency $25 \mathrm{~km}$ south of Surabaya [13] [11, p. 1]. The following morning a family of five, comprises of a father, a mother, and their three children, rode two motorcycles into the Surabaya police headquarters and blew themselves up at the entrance [11, p. 1]. The families were identified to have been connected with Indonesian pro-IS group known as Jemaah Ansharut Daulah (JAD).

The attack was observed as unprecedented approach to a terrorist attack particularly when family suicide bombers are involved in the process [14, Paras. 1-7]. The fact that women and children are participated in the combat of violent extremism shows that terrorism is no longer a role for only men to play. Before the IS incorporation of women into its organizational aparatus, "women in Indonesian jihadi organizations had far more traditional roles, such as wives, mothers, and teachers [11, p. 4]." The direct involvement of women in terrorist combat can be traced back to November 2005 when two suicide bombers, comprising of husband and wife, targeted three hotels in Amman, Jordan which killed 57 people [15, Para. 2].

As women play a more active role in the combat of pro-ISIS group in Indonesia, more are emboldened to carry out the attack themselves [11, p. 4]. While there are observations that the recruitment of women into a direct combat is a change of strategy on the part of pro-IS militant group when carrying out terrorist attacks [11, p. 4], women are now acting on their own and show willingness to take more risks in their role as member of violent extremist groups. This is exemplified by the emergence of female pro-IS sympathizers and supporters who are either helping their husbands create bombs or volunteered to be suicide bombers themselves $[11, \mathrm{p} .4]$. There is thus a shift in gender roles of extreme violence and terrorism particularly in the context of pro-IS militant groups in Indonesia. As explained in the 
subsequent paragraph, this conforms more to attributes of masculinity than femininity from psychological point of view.

There are two underlying approaches to defining and measuring the concepts of masculinity and femininity. The first approach involves the psychological view wherein measurements such as Terman-Miles M-F Test/Attitude Interest Analysis Test, Bem Sex-Role Inventory (BSRI), and Personal Attributes Questionnare (PAQ) are used [4, p. 8]. Throughout these measurements, masculinity is characterized as those who are, among others, "independent," "active," "can make decisions easily," "willing to take risks," "acts as a leader [16] [17]." Feminism, on the other hand, is scaled by "gentle," "helpful to others," "understanding of others," affectionate," "sensitive to the needs of others [16] [17]." The physchological labelling of what constitutes masculinity and femininity demonstrates that such attributes bear little relevance to the changing role of women from traditional to direct combatants in violent extremism and terrorism. This is where the sociological approach to masculinity and femininity can serve as a more pertinent framework to advance the application of the two concepts into violent extremism and terrorism. According to the identity theory in sociology, what constitutes masculinity and femininity depends on the social interaction that each individuals have undergone in various situations [18] [2, p. 274]. For that reason, it is possible for male and female to embrace either of the gender identities' attributes, i.e. masculinity and femininity, which is driven by the social interactive situations that they engage in. Consequently, the attempt to redefine masculinity and femininity in violent extremist and terrorism, with particular attention to pro-IS militant group in Indonesia, needs to take into account the interaction between male and female combatants within such militancy.

As stated in the first set of literature review as well as the conceptualization and operationalization of gender identities from psychological and sociological perspectives, masculinity and femininity is determined by social surroundings rather than biological factors. Because Islamist militant organization after the entry of IS changes its approach to encourage women combat in terrorist attack, the perception that women serve as a traditional and supporting role to men may no longer be seen as an inherent norm and expectation of violent Islamic extremist groups. It is thus vital to assess whether gender identity embodied in masculinity and femininity needs to be reconceptualized in the discourse of violent extremism. The attribute of masculinity as "violent" and femininity as "non-violent" is no longer pertinent when discussing gender roles in violent extremist combat. There is a shift from traditional and supporting role of women as men's companion in carrying out violence to a willingness of becoming participants in action. As a result, the dichotomy of "violence" and "non-violence" attributed to masculinity and femininity respectively has to be refined with another categorization that would describe more accurately the gender identity of both sexes. The underlying incentives and social interactions towards women's participation in violent extremist act can serve as a framework to redefine the attribute of masculinity and femininity in violent extremism.

\section{CONCLUSIONS}

The 2018 Surabaya Bombings and the involvement of women and children as a combat to violent extremism and thus terrorist act demonstrates that the norms and expectations of gender roles in that area has never been constant. As norms and expectations between male and female change, measurements to determine what is masculine and feminine in violent extremism and terrorism becomes likewise important. 
Since the role and identity of men and women are socially constructed, the deconstruction of that norms and expectations are most evident when the IS network begins to take a more pragmatic approach in increasing the will of women to participate in combat. This shift in traditional to participatory role of women in violent extremism has implications towards gender identity attributed to masculinity and femininity. As the development of these two concepts are heavily reliant on social interaction, continuous examination to that process will help shape the attribute that strengthens the accuracy of gender identity in violent extremism.

\section{REFERENCES}

[1] E. Pearson, “Why Men Fight and Women Don't: Masculinity and Extremist Violence Institute for Global Change," 2018. [Online]. Available: https://institute.global/insight/co-existence/why-men-fight-and-women-dontmasculinity-and-extremist-violence. [Accessed: 19-Nov-2019].

[2] P. J. Burke, J. E. Stets, M. a Pirog-good, and J. a N. E. Stets, "Gender Identity, SelfEsteem, and Physical and Sexual Abuse in Dating Relationships," Soc. Psychol. Q., vol. 51, no. 3, p. 274, 2013.

[3] M. Kimmel, The Gendered Society, 4th ed. New York: Oxford University Press, 2011.

[4] J. E. Stets and P. J. Burke, "Femininity/Masculinity," Encyclopedia of Sociology. Macmillan, New York, p. 1, 2012.

[5] J. Ezekilov, "Gender 'Men-Streaming ' CVE: Countering Violence Extremism by Addressing Masculinities Issues,” p. 2, 2017.

[6] M. Evangelista, Gender, Nationalism, and War: Conflict on the Movie Screen, 1st ed. Cambridge: Cambridge University Press, 2011.

[7] C. Enloe, The Curious Feminist: Searching for Women in a New Age of Empire, 1st ed. Berkely and Los Angeles: University of California Press, 2004.

[8] Organization for Security and Cooperation in Europe (OSCE), Understanding the Role of Gender in Preventing and Countering Violent Extremism and Radicalization That Lead to Terrorism Good Practices for Law Enforcement. Vienna: Organization for Security and Co-operation in Europe, 2019.

[9] N. C. Fink, S. Zeiger, and R. Bhulai, "A Man's World? Exploring the Roles of Women in Countering Terrorism and Violent Extremism," 2016.

[10] H. Khelghat-Doost, "Women of the Caliphate: The mechanism for women's incorporation into the Islamic State (IS)," Perspect. Terror., vol. 11, no. 1, pp. 18-19, 2017.

[11] K. E. Schulze, "The Surabaya Bombings and the Evolution of the Jihadi Threat in Indonesia," CTC Sentin., vol. 11, no. 8, pp. 1-4, 2018. 
[12] BBC News, "Surabaya church attacks: One family responsible, police say - BBC News," 2018. [Online]. Available: https://www.bbc.com/news/world-asia-44100278. [Accessed: 20-Nov-2019].

[13] T. Maharani, "Fakta-fakta Ledakan Bom di Sidoarjo Sejauh Ini," 2018. [Online]. Available: https://news.detik.com/berita/d-4018994/fakta-fakta-ledakan-bom-disidoarjo-sejauh-ini. [Accessed: 03-Dec-2019].

[14] S. Jones, "Surabaya and the ISIS family," 2018. [Online]. Available: https://www.lowyinstitute.org/the-interpreter/surabaya-and-isis-family. [Accessed: 19Nov-2019].

[15] G. Packer, "Why ISIS Murdered Kenji Goto," The New Yorker, 2015. [Online]. Available: https://www.newyorker.com/news/daily-comment/isis-murdered-kenjigoto. [Accessed: 26-Feb-2020].

[16] “Bem Sex-Role Inventory (BSRI),” 2007.

[17] "Personal Attributes Questionnaire (Spence, Helmreich \& Stapp, 1973)."

[18] S. Stryker, Symbolic Interactionism: A Social Structural Version, vol. 11, no. 1. Menlo Park: Benjamin-Cummings Publishing Company, 1980. 